Borneo Journal of Social Science \& Humanities

DOI: https://doi.org/10.35370/bjssh.2021.3.2-01

e-ISSN: 2682-8235

(C) 2018, UCTS Publisher

Submitted: 15 March 2021

Accepted: 2 December 2021

Published: 31 December 2021

\title{
Consumers' Attitudes towards Piracy: A Study in Sibu Division Sarawak
}

\author{
Abdul Rahman Edruce Kushairi*1, Rahmat Aidil Djubair ${ }^{2}$ and Wahida Wahi ${ }^{3}$ \\ ${ }^{1,2}$ School of Business and Management, Business Marketing Programme, University of \\ Technology Sarawak, No 1. Jalan Universiti, 96000 Sibu \\ ${ }^{3}$ School of Built Environment, Quantity Surveying Programme, University of Technology \\ Sarawak, No 1. Jalan Universiti, 96000 Sibu \\ *Corresponding author: abdulrahman@ucts.edu.my
}

\begin{abstract}
The use of optical discs is common in Malaysian society nowadays. It is widely used at different workplaces as well as for personal use at home. This indirectly opens up space for some opportunists to get benefits from the use of this technology. Among the notable effects is the occurrence of endless piracy problems. Most countries suffer from this problem, but more developed countries have managed to reduce this piracy issue. However, piracy is still rampant in Malaysia, especially in small-town outside the capital and major cities. The primary purpose of this study is to determine the attitude towards piracy among consumers in Sibu, Sarawak. The Theory of Planned Behaviour is chosen as the framework for this study. The objectives of this research focus on the respondents' practices and the factors contributing to piracy. The population of the Sibu Division is 162,676 people, and the study involved 112 respondents. Respondents were selected using systematic random sampling. A self-administered questionnaire was used to gather data from respondents engaged in the selling of pirated optical discs. This study revealed that consumers' behaviour shows neutrality towards piracy with a mean of 3.0904. Most of the respondents neither agreed nor disagreed with the fact that consumers' behaviour affects piracy. Regarding consumers' attitudes, subjective norm, and perceived behaviour control, the mean values are 3.4752, 2.9934, and 3.5165, respectively. These three independent variables show their neutrality towards consumers' intention of purchasing pirated products. The respondents displayed neutrality regarding the impact of consumer attitude, subjective norm, and perceived behaviour control against piracy. This means that other significant factors, apart from the listed independent variables, influence the attitude and behaviour towards piracy. In summary, subjective norm had the highest positive relationship among the three variables, followed by perceived behaviour control and consumer attitude. This shows that subjective norms play a critical role in influencing the behaviour of the respondents towards piracy in Sibu, Sarawak.
\end{abstract}

Keywords: Attitude towards Piracy, Perceived Behavioral Control, Subjective Norm, Theory of Planned Behavior 


\section{Introduction}

Optical disc technology has undeniably contributed to and has grown exponentially in education, business, public, and home-based industries. After independence, Malaysia has been ensuring overall development irrespective of the various market products resulting from intellectual properties. A significant problem in the development of intellectual property, which is not limited to Malaysia alone, is piracy. The most used piracy method is to reproduce programs or data without the consent of the copyright owner, law, or author of the program based on the agreement made between the creator and the producer.

Though the Malaysian government has been trying to control optical disc piracy as much as possible (Haque, Tarofder, \& Rahman, 2011), it has not fully achieved its aim. This is because no law in the world can altogether abolish this activity. Malaysia is seen as more committed to piracy than other Southeast Asia (referring to Thailand and Indonesia). It is common knowledge that piracy in the country is still rampant. The sale and distribution of pirated products are concentrated in major cities such as Kuala Lumpur, Georgetown, Melaka, and Johor Bahru and has spread to other areas such as small towns and even rural areas. In East Malaysia, the scenario of selling pirated products is no less impressive than in Peninsular Malaysia (Amirullah \& Ravindran, 2018). However, this is unknown because of the lack of coverage by the mainstream media to the extent that not many parties, especially the authorities, are aware of the piracy scenario in both states.

\section{Research Objectives}

The main objective of this study is to examine attitudes towards piracy among consumers in Sibu Division, Sarawak, Malaysia. Besides, this study also intends to determine the consumers' behaviour in rural areas about piracy and its factors. These objectives are drawn based on the Theory of Planned Behavior because it is a theory that is widely used in determining human behaviour towards specific issues.

\section{Literature Review}

\section{Consumer Behaviour Against Piracy}

Behaviour plays an essential role in consumers' decision-making. In addition, prior research has examined the contributors to the attitude in a scattered, non-uniform way, often reaching contrasting results. Such oversight is unfortunate because it will remain difficult for practitioners to change consumer behaviours without understanding the critical contributors to attitudes towards piracy (Ludovica \& Alberto, 2014).

\section{Consumer Attitudes Against Piracy Product}

Consumer attitudes refer to a particular person's feelings, tendencies, and considerations towards a product or service. There are varieties of concepts, images, and traits regarding consumer attitudes that will bring benefits to marketing. They are actual self-concept, ideal self-concept, expected self-image, inner-directedness, personality traits, consumer innovativeness, ethnocentrism, optimum stimulation level, and dogmatism (Schiffman \& Kanuk 2004). Presently, because of the affordability of pirated products, consumers have increasingly relied on purchasing and using those products for their survival (Eisend \& Schuchert, 2006). This situation may have made consumers' attitudes toward piracy 
generally acceptable (Ang, Cheng, Lim, \& Tambyah, 2001). Consumers' attitudes have a significant relationship towards piracy because of the prices of the products and social influence among consumers. Marketers or sellers have always paid more attention to setting or designing the prices of pirated products.

Regarding social impact, the younger ones always want to express their leading status by using pirated products. Consumers will always want to purchase pirated products because they are beneficial (Essays, 2018). A study showed that consumer attitude towards piracy was significant. Additionally, consumers who have favourable purchasing attitudes towards pirated products are intended to buy them for others, such as relatives, families, and friends, even recommend the pirated products to others (Ayupp \& Ismail, 2008). According to Nia and Zaichkowsky's (2000), consumers who buy, own, and utilise pirated products have a positive perception regarding piracy and would never think of it as a low-graded purchase intention within society.

Furthermore, novelty-seeking has been an essential determinant that builds a relationship between consumers' attitudes and piracy. People nowadays are willing to invest their money in purchasing low-cost pirated novel products to satisfy their curiosity (Wang, Zhang, \& Ouyang, 2005). Sometimes, price is a determining factor when it comes to consumers' attitudes towards piracy. That is to say, since both the pirated products and original products are meant to serve the same purpose, consumers would instead prefer to buy the product at a lower price. So, if the price of the pirated product is more affordable than that of the original, consumers will choose the pirated ones (Cordell, Wongtada, \& Kieschnick, 1996).

\section{Subjective Norm Against Piracy}

Subjective norm operates explicitly on a social level. It is a consciousness an individual has concerning either exhibiting or not exhibiting a particular behaviour towards a person or belief that is important to them (Ajzen, 1985). Perceptions of social and peer pressure are the antecedents of subjective norms that stimulate consumers to purchase pirated products. Consumers tend to invest in pirated products once they notice a culture of piracy in society (Ajzen, 1991). On the other hand, peer pressure, relatives, colleagues, classmates, or siblings around a particular buyer may arouse a kind of stress to stimulate a sense of piracy to acquire a product (Nancy, 1999). Previous research showed a significant relationship between subjective norm and piracy, which means the purchaser can be easily influenced and encouraged by their peers to engage in buying a pirated product (Chaipoopirutana \& Combs, 2011). Previous research found out that subjective norm has a positive impact on intent to purchase pirated goods (Peace, Galleta, \& Thong, 2003).

Moreover, another research finding concluded that subjective norm have been one of the crucial predictors of a tendency towards piracy (Morton \& Koufteros, 2008). There is another ethical-related statement revealing that subjective norm is a moral obligation. Buyers may try to avoid enduring the social pressures by admitting that piracy is unethical conduct and try not to perform it (Yoon, 2011). Justice acts as an ethical standard in the world to make a distinction between rights and wrong. Therefore, it is summarized that justice does negatively affect subjective norms towards piracy. Besides, subjective norms have been a factor that influences a purchaser's tendency towards purchasing pirated products, and it has always been a facilitating condition that stimulates the sense of piracy (Skykes \& Matza, 1957). 


\section{Perceived Behavioral Control Against Piracy}

Perceived behavioural control is more on personalised management. It is described as a consumer's consciousness of whether performing a purchasing behaviour is under their control or not (Ajzen \& Fishbein, 1975). Perceived behavioural control can influence a consumer's tendency by influencing personal decisions via behaviours. Perceived behavioural control is a significant positive predictor of the pirated product (Morton et al., 2008; Peace et al., 2003). In moral obligation, perceived behavioural control is considered in the unethical behavior context, which means that justice is found to have a negative impact on perceived control behaviour (Ajzen, 2005). Apart from that, perceived behavioural control is correlated to the ease of purchasing pirated products (Compeau \& Higgins, 1995). The more favourable the attitude towards a behaviour, the greater the perceived behavioural control and the stronger the sense of an individual's intention to invest in pirated products. Sometimes, it goes into two aspects: the ability of a person in controlling their behaviour, and how much confidence a person has in being able to perform or not regarding the behaviour (Ajzen, 1991). Perceived behavioural control is likely to buy pirated products (LaRose, Lai, Lange, Love, \& Wu, 2005). This is due to the consumer's sense of seeking novelty. People with higher perceived behavioural control are keen to engage in piracy activities (purchase or invest in pirated products) (Leonard \& Cronan, 2001; Phau, Lim, Liang, \& Lwin, 2014). Past studies also found that perceived behavioral control acts as a significant predictor in consumers' intention to buy a pirated product (Alleyne, Soleyn, \& Harris, 2015; Chang, 1998).

\section{Underlying Theory}

Some theories are related to the study of attitude and behaviour, especially towards human beings. The theories are the Theory of Reasoned Actions (TRA) and Theory of Planned Behaviour (TPB). This study adopted TPB as the underlying theory. Both approaches have their advantages, but TPB is chosen because it is more recent than TRA.

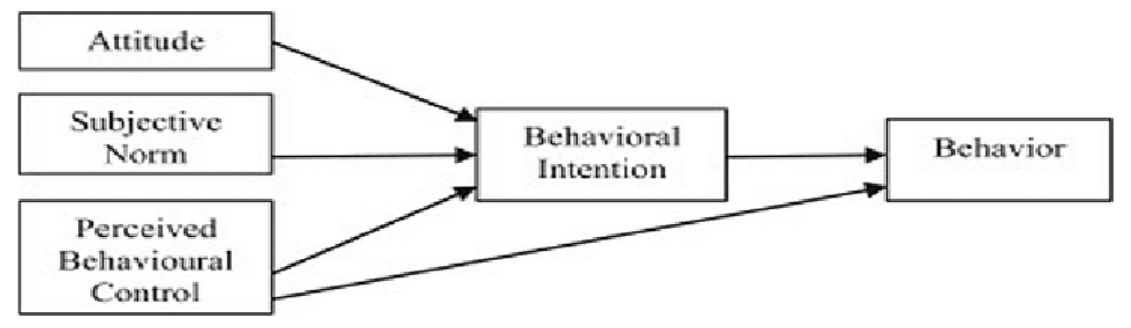

Figure 1: Theory of Planned Behavior

Source: Ajzen \& Fishbein (1985)

\section{Methodology}

\section{Research Instrument}

The research method applied in this study is the quantitative method. Respondents (consumers) targeted to answer the questionnaire are those citizens currently located in Sibu District. The respondents comprise of various gender, age hierarchies, and various backgrounds of ethnicity, religion, education, and occupational status. Roscoe (1975) states that sample sizes which is larger than 30 and less than 500 are appropriate for most research, so a sample size of 100 respondents was chosen from the population for this 
study. Additionally, the sampling technique adopted for this study is systematic random sampling.

A self-administered questionnaire was used as a data collection instrument. Customers who provide or sell pirated products were approached directly in their various shops or premises to collect data. All the data was treated and analysed using IBM SPSS software (Statistical Product and Service Solutions) to determine consumers' attitudes in Sibu District towards piracy.

\section{Questionnaire}

The main objective of the study is to measure the purchasing intention of pirated products among consumers. Next, the researchers examine the most influential factors (consumer attitudes, subjective norms, and perceived behavioural control) relating to piracy in Sibu, Malaysia. A set of questionnaires was developed to elicit responses to piracy's perceived factors, as shown in Table 2. In more detail, this questionnaire was intended to study the level of piracy intention and determine the element that has the most impact on piracy by looking into the responses from consumers located in Sibu, Malaysia. The questionnaire consisted of 48 items: 10 items were designed for each of the independent variables and 18 items were designed for the dependent variable. All items in this study were adopted from Abdul, Syuhaily, and Ahmad Hariza (2011). The Likert-type scale (the psychometric scale) was employed as a rating scale to measure the construct. According to the respondent's degree of agreement, all the items were responded to five points in likert scale; they were 1- strongly disagree, 2- disagree, 3- neutral, 4- agree, and 5- strongly agree.

\section{Data Description}

\section{Data Descriptions: Sample Population and Category}

The survey was conducted in Sibu District (central region of Sarawak) and 121 respondents were involved in this survey. As indicated in Table 1, the participants are male (44.6\%) and female (55.4\%); they are between ages of 20 and 29 (76.9\%); the majority of them are Chinese $(67.8 \%)$; various occupational backgrounds identified are students $(43.8 \%)$, private $(32.2 \%)$, self-employed (13.2\%), government $(6.6 \%)$, and other occupations such as delivery service and banking. The respondents were comprised of five different educational levels: secondary school $(5.8 \%)$, certificate $(5.0 \%)$, diploma $(16.5 \%)$, degree $(63.6 \%)$, and master/PhD (9.1\%). Various religious backgrounds include Islam (13.2\%), Christian (60.3\%), Hindu (1.7\%), Buddha (16.5\%), Animist (0.8\%), and others $(7.4 \%)$.

Table 1: Demographic Profile of Respondents $(\mathrm{N}=121)$

\begin{tabular}{lcc}
\hline & Frequency $(\mathrm{n})$ & Percentage $(\%)$ \\
\hline Gender & & \\
Male & 54 & 44.6 \\
Female & 67 & 55.4 \\
Ethnic & & \\
Chinese & 82 & 67.8 \\
Iban/Bidayuh/Orang Ulu & 16 & 13.2 \\
Malay & 11 & 9.1 \\
Melanau & 8 & 6.6 \\
\hline
\end{tabular}




\begin{tabular}{lcc}
\hline Indian & 4 & 3.3 \\
Age & & \\
20-29 years & 93 & 76.9 \\
30-39 years & 17 & 14.0 \\
40 years above & 8 & 6.6 \\
Below 19 years & 3 & 2.5 \\
Occupation & & \\
Student & 53 & 43.8 \\
Private & 39 & 32.2 \\
Self-employed & 16 & 13.2 \\
Government & 8 & 6.6 \\
Others & 3 & 2.5 \\
Banking & 1 & 0.8 \\
Delivery service & 1 & 0.8 \\
Education Level & & \\
Degree & 77 & 63.6 \\
Diploma & 20 & 16.5 \\
Master/PHD & 11 & 9.1 \\
Secondary School & 7 & 5.8 \\
Certificate & 6 & 5.0 \\
Religion & & \\
Christian & 73 & 60.3 \\
Buddha & 20 & 16.5 \\
Islam & 16 & 13.2 \\
Others & 9 & 7.4 \\
Hindu & 2 & 1.7 \\
Animist & 1 & 0.8 \\
\hline Source: Author & &
\end{tabular}

Source: Author

Concerning Cronbach's Alpha score, the internal consistency of the measurement of various variables is shown in Table 2. Internal consistency for the dependent variable (respondent's Behavior towards Piracy) and independent variable (Consumers' Attitudes) is acceptable $(0.8>\alpha>0.7)$. The independent variables (Subjective Norms and Perceived Behavior Control) obtained good internal consistency $(0.9>\alpha>0.8)$. Reliability is the measurement of internal consistency and data stability. The degree of consistency of the various variables included in this survey was indicated using Cronbach's Alpha and its accepted internal consistency.

Table 2: Reliability Testing: Cronbach Alpha $(\mathbf{N}=121)$

\begin{tabular}{|c|c|c|c|}
\hline Variables & $\begin{array}{l}\text { Number of } \\
\text { items }\end{array}$ & $\begin{array}{l}\text { Cronbach's Alpha } \\
(\alpha)\end{array}$ & $\begin{array}{c}\text { Internal } \\
\text { Consistency }\end{array}$ \\
\hline $\begin{array}{lll}\text { Respondent's } & \text { Behavior } & \text { Towards } \\
\text { Piracy } & & \end{array}$ & 18 & .738 & Acceptable \\
\hline Consumer Attitudes & 10 & .732 & Acceptable \\
\hline Subjective Norms & 10 & .820 & Good \\
\hline Perceived Behavioral Control & 10 & .816 & Good \\
\hline
\end{tabular}

Source: Author

\section{Results and Discussion}

As mentioned in the methodology, all questions in the questionnaire were developed and answered on a 5-Point Likert Scale. They are: 1- strongly disagree, 2-disagree, 3-neutral, 4-agree, and 5-strongly agree. Table 3 summarises the descriptive analysis of all variables. 
In analysing the mean analysis table, four mean variables were revealed ( 1 dependent variable and three independent variables). Consumers' behaviour towards piracy revealed a mean of 3.0904; this means that consumers' behaviour shows neutrality. Most of the respondents neither agreed nor disagreed concerning whether consumer behaviour affects piracy or not. In addition, regarding consumers' attitudes, subjective norm and perceived behavioural control, with mean figures of 3.4752, 2.9934, and 3.5165 respectively. These results suggest that the three independent variables show neutrality towards consumers' intentions in purchasing the pirated product in Sibu. The respondents displayed neutral responses regarding the impact of consumers' attitudes, subjective norms, and perceived behavioural control against piracy.

Table 3: Descriptive Analysis of the Variables $(\mathrm{N}=121)$

\begin{tabular}{lcccc}
\hline Variables & Min. & Max. & Mean & Standard Deviation \\
\hline Consumer's Behaviour Towards Piracy & 1.89 & 5.00 & 3.0904 & .47494 \\
Consumer Attitude & 1.60 & 5.00 & 3.4752 & .58228 \\
Subjective Norm & 1.40 & 5.00 & 2.9934 & .65265 \\
Perceived Behavior Control & 1.70 & 5.00 & 3.5165 & .63945 \\
\hline
\end{tabular}

Source: Author

As demonstrated in Table 4, the result indicates a significant relationship between the dependent variable (consumer's behaviour towards piracy) and the three independent variables (consumer attitude, subjective norm, and perceived behavioural control). Subjective norms have the highest association with consumers' behavior towards piracy ( $\mathrm{r}$ $=0.659, \mathrm{p}<0.01)$, followed by perceived behavioral control $(\mathrm{r}=0.626, \mathrm{p}<0.01)$, and consumers' attitude $(\mathrm{r}=0.351, \mathrm{p}<0.01)$.

From Table 4, piracy is dedicated as acquiring a very significant relationship with three independent variables: consumer attitude, subjective norm, and perceived behavioural control with a 2-tailed significance of 0.000 for each and vice versa. All the relationships between independent variables proved to be significant. Moreover, there is a correlation between three independent variables: consumer attitude, subjective norm, and perceived behavioural control with consumer behaviours towards piracy which are 0.351 , 0.659 , and 0.626 respectively.

Table 4: Relationship among Variables

\begin{tabular}{|c|c|c|c|c|}
\hline & $\begin{array}{c}\text { Consumer's } \\
\text { Behaviors } \\
\text { Toward Piracy }\end{array}$ & $\begin{array}{l}\text { Consumer } \\
\text { Attitude }\end{array}$ & $\begin{array}{c}\text { Subjective } \\
\text { Norm }\end{array}$ & $\begin{array}{c}\text { Perceived } \\
\text { Behavior } \\
\text { Control } \\
\end{array}$ \\
\hline Consumer's Behavior Towards Piracy & 1 & & & \\
\hline Consumer Attitude & $.351^{* *}$ & 1 & & \\
\hline Subjective Norm & $.659^{* *}$ & $.207^{*}$ & 1 & \\
\hline Perceived Behavior Control & $.626^{* *}$ & $.435^{* *}$ & $.708^{* *}$ & 1 \\
\hline
\end{tabular}

Source: Author

The correlation coefficient given range proves that there is a moderate positive linear relationship between consumer attitude $(0.3<0.351 \leq 0.7)$, subjective norm $(0.3<$ $0.659 \leq 0.7)$, perceived behavioral control $(0.3<0.626 \leq 0.7)$ and piracy. Ratner $(2009)$ mentions that the higher the value, the stronger the positive relationship between dependent and independent variables. Thus, it is depicted in Table 5 that the highest positive relationship goes to subjective norm with the correlation of 0.659 , the second 
goes to perceived behavioural control with the correlation of 0.626 , and the last goes to consumer attitude with the correlation of 0.351 .

Table 5: Correlation Order

\begin{tabular}{lcc}
\hline Variables & Pearson Correlation & Positivity Relationship Order \\
\hline Subjective Norm-Piracy & 0.659 & 1 \\
Perceived Behavior Control-Piracy & 0.626 & 2 \\
Consumer Attitude-Piracy & 0.351 & 3 \\
\hline
\end{tabular}

Source: Author

\section{Discussion}

This present study discovers a significant relationship between consumers' attitudes towards pirated products and their behaviour towards piracy $(r=0.351, p<0.01)$, which is in line with earlier studies (Ayupp \& Ismail, 2008; Eisend \& Schucher, 2006; Wang et al., 2005). The more positive/favourable the attitude towards digital piracy is, the more an individual commits the act, and vice versa. On the five-point Likert scale, the mean score for consumers' attitudes is 3.48, suggesting that consumers in the Sibu Division tend to have a somewhat positive attitude towards piracy. The price and quality of the pirated products provide a chance for the consumer to support piracy. Another reason is the recommendations from friends and family.

Similar to the findings of Chaipoopirutana and Combs (2011) and Peace et al. (2003) studies, this study shows a close relationship between subjective norms and consumer behaviour towards piracy $(\mathrm{r}=0.659)$. Ajzen (1988) postulated that subjective norms refer to how an individual perceives referent groups' (parents, friends, faculty, etc.) pressure on them to perform or not to perform a given behaviour. The more referent groups approve of specific behaviour, the more likely they will execute it. When the individual's attitude towards behaviour and the encouragement of reference groups to perform such acts are firm, the person will be more likely to adopt the behaviour. This study suggests that the attitudes and behaviour of consumers concerning piracy in Sibu Divisions are highly influenced by their peers. The greater the influence of peers, the greater the consumers' tendency to purchase pirated products. Contrarily, inhibitions are created when peers and other influential members of one's social group (family, school staff, etc.) are perceived to be anti-piracy.

Furthermore, perceived behavioural control affects consumers' behaviour towards piracy $(\mathrm{r}=0.626, \mathrm{p}<0.01)$. The mean scores for all items of perceived behavioural control are 3.52, suggesting that consumers, especially in the Sibu Division, are not always guilty when they are committed to buying pirated products and services. The more favourable the attitude towards piracy behavior, the greater the perceived behavioral control and the stronger the inclination of an individual's intention to invest in pirated products. The ease of opportunities for getting pirated products and services might influence consumers to perform piracy.

\section{Conclusions}

In this article, the researchers have analysed Sibu district's consumers' piracy intention according to three variables: subjective norms, perceived behavioural control and 
consumer attitude. The results have shown that these three variables are significantly related to piracy intention. Firstly, the finding indicates that subjective norms has the greatest influence in affecting a consumer's piracy intention. They are mainly associated. It means one's intention to buy pirated products can be influenced by the people around them since their opinions are essential to that particular consumer. A consumer may receive some perceived expectations from others, which in turn can lead to action realization. For example, they can be colleagues, family members, friends, and neighbours. According to Peace et al. (2003), there is a strong association between subjective norms and one's intention of piracy. Subjective norms have been proved to positively and significantly impact consumers' piracy intention (Shah Alam \& Mohamed Sayuti, 2011). The second goes to perceived behaviour. Its influence is slightly weaker than the subjective norm. Perceived behaviour has a significant and moderately positive impact on the Sibu district's consumers' piracy intention.

Once one perceives that one has greater control or ability over what one is involved in piracy, one will primarily purchase pirated products (Hsing, Ronald, \& Hildy, 1997). This could apply to Sibu's consumers because they are stimulating and supporting their piracy intention in buying pirated products. Lastly, looking into the relationship between consumers' attitudes and piracy, this variable has the least positive and significant impact on piracy when compared with the other two variables. It means Sibu's consumers' intention to purchase pirated products may be affected by self-attitude, but not affected as much as the other two variables. Once an individual has a positive attitude towards purchasing pirated products, they will buy pirated products constantly (Wong et al., 1990). According to Peace et al. (2003), consumer's attitude is the most significant factor in influencing purchaser's piracy tendency. Therefore, the consumer attitude is closely associated with one's intention in purchasing pirated products (Khang, $\mathrm{Ki}, \&$ Baek, 2012).

\section{Recommendations and Limitations}

The relevance and implications of the Copyright Acts to piracy do not appear to be fully understood by the Sibu Division public. The government should make the general public more aware of the infringements of intellectual capital by making these laws more widely known and therefore be perceived as significant. Radio and television could be used to broadcast the rules and the penalties involved in digital piracy, as the medium of television and radio could be where the desire for certain digital media arises. A famous artist could be employed to run this initiative to make the public aware that artists are affected by their pirating behaviour. The individuals should be informed that soft lifting is also stealing from the producers even when not purchasing the pirated products and services. If one individual is prosecuted, and there is press coverage (newspaper, television, and radio) of their cases, individuals might be dissuaded from having a more lenient attitude towards piracy.

Attitudes towards digital piracy, subjective norms and perceived behaviour are the significant determinants of consumers' intention to pirate products and services. The main concern for combating piracy in Sibu is that there is a positive attitude and a low level of guilt towards piracy. It requires integrated efforts of all relevant parties, such as government, industry players, educators, and the public. Law enforcement and stricter 
ethical codes of conduct regarding intellectual property rights protection have to be consistently implemented. When applied, this will contribute to the development of negative attitudes and high levels of guilt towards piracy among consumers, which will reduce their intention to purchase pirated products and services. Despite its potential contributions, the present study has some limitations, such as the issue of generalizability due to its adopted sampling method, narrow range of population and a limited number of samples, limited geographical scope, analytical tools, and research methods. Further research could be designed to minimize these weaknesses.

\section{References}

Abdul, K., Shuhaily, O., \& Ahmad Hariza. (2011). Sikap masyarakat terhadap cetak rompak di Bahagian Mukah Sarawak. Jurnal Pengguna Malaysia, 16, 95-108.

Ajzen (1988). Attitudes, personality, and behavior. Milton Keyness, England: Open University Press.

Ajzen, I. (1985). From Intentions to actions: A Theory of Planned Behaviour. In: Kuhl J., Beckmann J. (Eds) Action Control. SSSP Springer Series in Social Psychology. Springer, Berlin, Heidelberg.

Ajzen, I. (1991). The Theory of Planned Behavior: Some Unresolved Issues. Organizational Behavior and Human Decision Processes, 50(2), 179-211.

Ajzen, I. (2005). Attitudes, personality, and behavior. McGraw-Hill Education (UK).

Ajzen, I. \& Fishbein, M. (1975). A Bayesian analysis of attribution processes. Psychological bulletin, 82(2), 261.

Alleyne, P., Soleyn, S., \& Harris, T. (2015). Predicting accounting students' intentions to engage in software and music piracy. Journal of Academic Ethics, 13(4), 291-309.

Amirullah, A. \& Ravindran, M. (2018). Digital Piracy in Malaysia. International Property Right Index, 1-12.

Ang, S.H., Cheng, P.S., Lim, A.C., \& Tambyah, S.K. (2001). Spot the differences: Consumer responses towards counterfeits. Journal of Consumer Marketing, 18(3), 219-235.

Ayupp, K. \& Ismail, R. (2008). Analysis of consumers' attitudes and behaviors towards pirated products. International Journal of Information, Business and Management, 3(1), 53-60.

Chaipoopirutana, S. \& Combs, H. (2011). An empirical study of consumer attitudes toward software piracy. ACR Asia-Pacific Advances.

Chang, M.K. (1998). Predicting unethical behaviour: A comparison of the theory of reasoned action and the theory of planned behaviour. Journal of Business Ethics, 17(16), 1825-1834.

Compeau, D.R. \& Higgins, C.A. (1995). Computer self-efficacy: Development of a measure and initial test. MIS quarterly, 19(2), 189-211.

Cordell, V.V., Wongtada, N., \& Kieschnick, Jr. R.L. (1996). Counterfeit purchase intentions: role of lawfulness attitudes and product traits as determinants. Journal of Business Research, 35(1), 41-53.

Eisend, M. \& Schuchert Guler, P. (2006). Explaining counterfeit purchases: A review and preview. Academy of Marketing Science Review, 2006(12), 1-22. 
Essays, UK. (2018). Factors influencing consumers' attitude towards pirated products. Retrieved from https://www.ukessays.com/essays/marketing/factors-influencingconsumers-attitude-towards-pirated-products-marketing-essay.php?vref=1

Haque, A., Tarofder, A.K., \& Rahman, S. (2011). Exploring critical factors choice of piracy products: An empirical investigation on Malaysian Customers. European Journal of Economics, Finance and Administrative Sciences, 30(30), 84-94.

Hsing K.C., Ronald R.S., \& Hildy T. (1997). To Purchase or to Pirate Software: An Empirical Study. Journal of Management Information Systems, 13(4), 49-60.

Khang, H., Ki, E., \& Baek, S. (2012). Exploring antecedents of Attitudes and Intention towards internet piracy among college students in South Korea. Asian Journal of Business Ethics, 1(2), 177-194.

LaRose, R., Lai, Y.J., Lange, R., Love, B., \& Wu, Y. (2005). Sharing or piracy? An exploration of downloading behavior. Journal of Computer-Mediated Communication, 11(1), 1-21.

Leonard, L. \& Cronan, T.P. (2001). Illegal, inappropriate, and unethical behavior in an information technology context: A study to explain influence. Journal of the Association for Information Systems, 1(12), 1-31.

Ludovica, C. \& Alberto, P. (2014). Consumer's attitude and behavior towards online music piracy and subscription-based services. The Journal of Consumers Marketing, 31(6/7), 515-525.

Morton, N.A. \& Koufteros, X. (2008). Intention to commit online music piracy and its antecedents: An empirical investigation. Structural Equation Modeling, 15(3), 491-512.

Nancy, D. (1999). Consumer Misbehavior: Why People Buy Illicit Goods. Journal of Consumer Marketing, 16(3), 273-287.

Nia, A. \& Zaichkowsky, J.L. (2000). Do counterfeits devalue the ownership of luxury brands? The Journal of Product and Brand Management, 9(7), 485-93.

Peace, A.G., Galletta, D.F., \& Thong, J.Y.L. (2003). Software piracy in the workplace: A model and empirical test. Journal of Management Information System, 20(1), 153177.

Phau, I., Lim, A., Liang J., \& Lwin, M. (2014). Engaging in digital piracy of movies: a theory of planned behaviour approach. Internet Research, 24(2), 246-266.

Ratner, B. (2009). The correlation coefficient: Its values range between +1 and -1 , or do they? Journal of Targeting, Measurement and Analysis for Marketing, 17, 139142.

Roscoe, J.T. (1975). Fundamental Research Statistics for the Behavioral Sciences. $\left(2^{\text {nd }}\right.$ $E d$.$) . New York: Holt, Rinehart and Winston$

Schiffman, L. \& Kanuk, L. (2004). Consumer Behavior. (8th ed.). Upper Saddle River, New Saddle River, New Jersey: Prentice Hall.

Shah Alam, S. \& Mohamed Sayuti, N. (2011). Applying the Theory of Planned Behavior (TPB) in halal food purchasing. International Journal of Commerce and Management, 21(1), 8-20.

Sykes, G. \& Matza, D. (1957). Techniques of neutralization: a theory of delinquency. American Sociological Review, 22(6), 664-670. 
Wang, F., Zhang, H., \& Ouyang, M. (2005). Software Piracy and Ethical Decision Behaviour of Chinese Consumers. Journal of Comparative International Management, 8(2), 56-63.

Wong, G., Kong, A., \& Ngai, S. (1990). A Study of Unauthorized Software Copying among Post-Secondary Students in Hong Kong. The Australian Computer Journal, 22(4), 114-122.

Yoon, C. (2011). Theory of planned behavior and ethics theory in digital piracy: An integrated model. Journal of Business Ethics, 100, 405-417. 